\title{
COMPATIBILITY OF Heterorhabditis amazonensis MC01 (Nematoda: Rhabditida) WITH FERTILIZERS AND SOIL CONDITIONERS
}

\author{
COMPATIBILIDADE DE Heterorhabditis amazonensis MC01 (Nematoda: Rhabditida) \\ COM FERTILIZANTES E CONDICIONADORES DE SOLO
}

\author{
Vanessa ANDALÓ ${ }^{1}$; Fernando da Silva ROCHA ${ }^{2}$ Lucas Silva de FARIA $^{\mathbf{1}}$ \\ 1. Universidade Federal de Uberlândia, Campus Monte Carmelo, Monte Carmelo, MG, Brasil; 2. Universidade Federal de Minas Gerais, \\ Campus Montes Claros, Montes Claros, MG, Brasil. vanessaandalo@ufu.br
}

\begin{abstract}
Entomopathogenic nematodes are natural enemies of insect pests present in the soil; however, the intensive use of agricultural inputs can affect the action of these organisms. The objective of this study was to evaluate the effects of exposure of the nematode Heterorhabditis amazonensis MC01 to soil fertilizers containing different active ingredient, verifying their influence in the viability, infectivity and nematode production in Tenebrio molitor L. larvae. Nine products were tested, including fertilizers and soil conditioners, using the adapted IOBC/WPRS protocol. The infective juveniles were exposed to the highest concentration recommended by the manufacturer of each product for a period of $48 \mathrm{~h}$. After this period, the viability, infectivity and production were evaluated and the values of mortality, infectivity reduction, production reduction and insecticide effect were obtained in order to classify the products according to IOBC criteria. In this way, the nematode $H$. amazonensis MC01 was compatible with most of the products under the tested conditions, so could be present in the soil at the same time. However, the product Nutriterge ${ }^{\circledR}$ Formula 3 was considered slightly harmful and Nem out ${ }^{\circledR}$ considered harmful. However, further field tests should be performed with these products to prove the deleterious effect on the nematode tested.
\end{abstract}

KEYWORDS: Biological control. Botanical extract. Heterorhabditidae. Organic agriculture.

\section{INTRODUCTION}

Entomopathogenic nematodes (EPNs) are organisms that live part of their life in the soil. In order to survive the adverse factors found in this environment, these organisms have a stage of development known as infective juvenile (IJ), which is adapted to the conditions found outside the host (SOMMERVILLE; DAVEY, 2002).

Environmental factors directly influence EPN populations in soil, such as humidity, temperature and ultraviolet radiation (DOLINSKI et al., 2017). However, other factors may affect the presence of IJs in the soil, since these organisms live in an environment which continuously receives the addition of agricultural inputs, such as phytosanitary products, fertilizers and soil conditioners that will influence their survival and affect the natural ecosystems balance (GREWAL et al., 2001). Even the combination of EPNs with microorganisms, also used as biocontrol agents, can cause a negative effect, as occurs with Heterorhabditis bacteriophora Poinar, whose survival is affected when in contact with Bacillus thuringiensis Berliner (KAYA et al., 1995).
Studies related to the compatibility of EPNs with agricultural inputs demonstrate that nematodes could remain viable when in contact with several of these products (SABINO et al., 2017). According to Nishimatsu and Jackson (1998) some insecticides used in sublethal doses may act in synergism with EPNs, increasing the effectiveness of pest control. However, some of them can cause a reduction in infectivity or even kill the IJs.

Studies about the compatibility between EPNs and phytosanitary products demonstrate that the interactions vary according to the species studied, so some species can be sensitive to a product and other species can have a synergistic effect when in contact with the same product (KOPPENHÖFER; GREWAL, 2005). In general, nematodes of the genus Heterorhabditis have shown greater sensitivity to phytosanitary products than Steinernema spp. (GREWAL et al., 1998). Thus, data obtained for one species of nematode should not be extrapolated to another, in order to avoid failure in controlling the insect pest.

The nematode Heterorhabditis amazonensis Andaló, Nguyen and Moino Júnior was isolated in 
Brazil in forest areas in the state of Amazonas and in areas of sorghum and garlic cultivation in the state of Minas Gerais (ANDALÓ et al., 2009), and this is a species adapted to local environmental conditions.

Thus, verifying the compatibility of $H$. amazonensis MC01 with different agricultural inputs, including new formulations introduced in the market is fundamental for the success of this nematode as a pest control agent.

Considering this context, the objective of this study was to evaluate the effects of different fertilizers and plant extracts when in contact with $H$. amazonensis MC01, evaluating the influence on their viability, infectivity and production.

\section{MATERIAL AND METHODS}

The tests were conducted in the Entomology Laboratory of the Federal University of Uberlândia. For the compatibility test between soil conditioners and fertilizers with entomopathogenic nematodes the IOBC/WPRS Protocol (VAINIO, 1992) was used.

The nematode tested was $H$. amazonensis MC01 obtained from the entomopathogen bank of the Entomology Laboratory stored in an aqueous suspension at a concentration of $1,000 \mathrm{IJ} \mathrm{mL}^{-1}, 16 \pm$ $1^{\circ} \mathrm{C}$, relative humidity of $70 \pm 10 \%$ and with a $24 \mathrm{~h}$ scotophase in a climate-controlled chamber. The nematode was isolated from the soil in a pasture area with Brachiaria decumbens (Hochst. ex A. Rich.) Stapf (Poaceae), using the insect-bait technique, using Tenebrio molitor L. larvae (Coleoptera: Tenebrionidae) in the municipality of Monte Carmelo, $\mathrm{MG}$, and was selected for the experiment because it is a species adapted to the edaphoclimatic conditions of the region.

For use in the experiment, the nematode was multiplied in the last instar of $T$. molitor larvae, with the use of IJs that were collected for up to three days after the emergence of the insect-cadaver. Tenebrio molitor was reared according to the methodology of Potrich et al. (2007).

The products tested (Table 1) were prepared at twice the highest dose concentration recommended by the manufacturer per $\mathrm{ml}$ of water. From this solution, $1 \mathrm{~mL}$ aliquot was removed and placed in five glass tubes $(8 \mathrm{~cm}$ high $\times 2.5 \mathrm{~cm}$ in diameter) per treatment, in which 2,000 IJs were added in $1 \mathrm{~mL}$ of distilled water. The tubes were sealed with Parafilm ${ }^{\circledR}$ and kept in a climate-controlled chamber at $25 \pm 1^{\circ} \mathrm{C}$, $70 \pm 10 \% \mathrm{RH}$ and $24 \mathrm{~h}$ of dark.

The viability of the nematodes was evaluated $48 \mathrm{~h}$ after exposure to the products. Ten aliquots of $0.1 \mathrm{~mL}$ of the suspension were withdrawn per tube, totaling $1 \mathrm{~mL}$, observing $100 \mathrm{IJs}$ per aliquot under a stereoscope microscope, and quantifying the number of dead nematodes. The juveniles that did not respond to the addition of $50 \mu \mathrm{l}$ of $1 \mathrm{~N} \mathrm{NaOH}$ were considered dead (CHEN; DICKSON, 2000).

After evaluating viability, the infectivity was tested by adding $3 \mathrm{~mL}$ of distilled water and left to decant for half an hour in a refrigerator at $10^{\circ} \mathrm{C}$. After this time the supernatant (about $3 \mathrm{~mL}$ ) was discarded and washing was repeated three times. After the last wash, $0.8 \mathrm{~mL}$ of the bottom of each tube was pipetted and added into a glass Petri dish $(9 \mathrm{~cm}$ diameter) containing two sheets of filter paper. Each dish received ten larvae of $T$. molitor, and was kept in a climate-controlled chamber in the same condition as before, for five days. After this period, the mortality of larvae caused by the IJs was verified, confirming the mortality through characteristic symptomatology and dissection, if necessary.

To obtain the IJ production data, 15 dead larvae per treatment (average size of $2.4 \mathrm{~cm}$ ), were transferred to White traps, which were maintained under the same conditions cited above. The juveniles produced by treatment were counted for five days, and later quantified in stereoscope microscope. The IJ viability and infectivity data were submitted to analysis of variance and Tukey test $(p<0.05)$ for comparison between means. Mortality values of the nematodes were corrected by the Abbott formula, described below:

$$
\mathrm{Cm} \%=\frac{0 \mathrm{~m} \%-\mathrm{Cm} \% \times 100}{100-\mathrm{Cm} \%}
$$

$\mathrm{Cm}=$ Corrected mortality; Om = Observed mortality; and $\mathrm{Cm}=$ Control mortality.

Infectivity was obtained by the percentage of $T$. molitor larvae mortality. The reduction of infectivity in the treatment compared to the control was obtained by the formula:

$$
\operatorname{Rinf} \%=\left(1-\frac{\mathrm{It} \%}{\mathrm{Ic} \%}\right) \times 100
$$


Table 1. Soil conditioners and fertilizers used in the study of compatibility with entomopathogenic nematodes.

\begin{tabular}{|c|c|c|c|}
\hline Trade mark & Composition & Description & Dose \\
\hline Compost Aid $^{\circledR}$ & $\begin{array}{l}\text { Cellulase } 6 \% \mathrm{w} / \mathrm{w} \text {; Amylase } 0.6 \% \mathrm{w} \mathrm{w}^{-1} \text {; } \\
\text { Lactobacillus plantarum } 1.5 \times 10^{-7} \mathrm{CFU} \mathrm{g}^{-1} \text {; } \\
\text { Bacillus subtilis } 1.5 \times 10^{-7} \mathrm{CFU} \mathrm{g}^{-1} ; \\
\text { Enterococcus faecium: } 1.5 \times 10^{-7} \mathrm{CFU} \mathrm{g}^{-1} \text {. }\end{array}$ & Foliar fertilizer. & $1 \mathrm{~kg} \mathrm{ha}^{-1}$ \\
\hline Copper Crop $^{\circledR}$ & $\begin{array}{c}\mathrm{N} \mathrm{sol.} \mathrm{H}_{2} \mathrm{O} 4.09 \%\left(54.81 \mathrm{~g} \mathrm{~L}^{-1}\right) ; \\
\mathrm{Cu} \text { sol. } \mathrm{H}_{2} \mathrm{O} 10.00 \%\left(134.00 \mathrm{~g} \mathrm{~L}^{-1}\right) ; \\
\text { organic carbon } 2.78 \% \text {; contains } 5 \% \text { amino acid complexing agent. }\end{array}$ & Foliar fertilizer/fungicide. & $400 \mathrm{~mL} 100 \mathrm{~L}^{-1}$ of water \\
\hline Soil Set ${ }^{\circledR}$ & $\begin{array}{c}\mathrm{S} 3.75 \% ; \mathrm{Cu} 2 \% ; \mathrm{Fe} 1.6 \% ; \mathrm{Mn} 0.8 \% ; \mathrm{Zn} 3.2 \% \\
\text { organic carbon } 1.58 \% \text {; contains } 5 \% \text { amino acid complexing agent. }\end{array}$ & Foliar fertilizer. & $200 \mathrm{~mL} 100 \mathrm{~L}^{-1}$ of water \\
\hline Full Matrix ${ }^{\circledR}$ & $\begin{array}{c}\text { Total organic carbon } 33 \%\left(\mathrm{~g} \mathrm{~L}^{-1}\right) \\
\mathrm{K}_{2} \mathrm{O} 7 \%\left(\mathrm{~g} \mathrm{~L}^{-1}\right) ; \text { leonardite; potassium hydroxide. }\end{array}$ & $\begin{array}{l}\text { Foliar organomineral } \\
\text { fertilizer. }\end{array}$ & $200 \mathrm{~g} \mathrm{ha}^{-1}$ \\
\hline Condisolo Premium ${ }^{\circledR}$ & $\begin{array}{c}\text { Total carbon (organic and mineral) } 27 \% \text {; organic carbon } 12.85 \% ; \\
\mathrm{N} \mathrm{1.66 \%} ; \mathrm{P}\left(\mathrm{P}_{2} \mathrm{O}_{5}\right) 4.85 \% ; \mathrm{Ca} 4.85 \% ; \mathrm{Mg} 3.61 \% ; \mathrm{S} \text { total } 0.38 \% ; \mathrm{Cu} 74 \\
\mathrm{mg} \mathrm{Kg}^{-1} ; \mathrm{Mn} \text { total } 616 \mathrm{mg} \mathrm{Kg}^{-1} ; \mathrm{Zn} \text { total } 875 \mathrm{mg} \mathrm{Kg}^{-1} ; \mathrm{Fe} \text { total } 12,359 \mathrm{mg} \\
\mathrm{Kg}^{-1} ; \mathrm{B} \text { total } 57 \mathrm{mg} \mathrm{Kg}^{-1} ; \mathrm{Na}^{-1} \text { tal } 1,740 \mathrm{mg} \mathrm{Kg}^{-1} ; \mathrm{C} / \mathrm{N} \text { ratio } 10 / 1 ; \mathrm{pH} \text { in } \\
0.01 \mathrm{M} \mathrm{CaCl}_{2} 7.9 .\end{array}$ & $\begin{array}{l}\text { Foliar organomineral, } \\
\text { added of Lithothamnium } \\
\text { (seaweed). }\end{array}$ & $25,000 \mathrm{~kg} \mathrm{ha}^{-1}$ \\
\hline Nem out ${ }^{\circledR}$ & $\begin{array}{l}\text { Protease enzymes, cellulase, xylanase; } \\
\text { Total microbial count } 3.75 \times 10^{8} \mathrm{CFU} \mathrm{g}^{-1}\end{array}$ & Additive for composting. & $15 \mathrm{Kg} \mathrm{ha}^{-1}$ \\
\hline Nutriterge ${ }^{\circledR}$ Formula 1 & $\begin{array}{l}65 \% \text { neem extract; } 15 \% \text { pyroligneous extract; } 5 \% \text { of coffee extract; } 2 \% \\
\text { phenolic compounds; } 15 \% \text { technical glycerin*. }\end{array}$ & Plant extract. & $90 \mathrm{~mL} \mathrm{~L}^{-1}$ of water \\
\hline Nutriterge ${ }^{\circledR}$ Formula 2 & $85 \%$ neem extract; $15 \%$ technical glycerin ${ }^{*}$ & Plant extract. & $90 \mathrm{~mL} \mathrm{~L}^{-1}$ of water \\
\hline Nutriterge ${ }^{\circledR}$ Formula 3 & $50 \%$ neem extract; $50 \%$ pyroligneous extract. & Plant extract. & $90 \mathrm{~mL} \mathrm{~L}^{-1}$ of water \\
\hline
\end{tabular}

*Technical glycerin - obtained from the acid hydrolysis of the phosphoric acid of the biodiesel manufacturing process. 
Rinf $\%=$ Reduction of infectivity; It $\%=$ Infectivity of the treatment; and Ic\% $\%$ Infectivity of the control.

The production was obtained by counting the number of IJs obtained from the larvae of T. molitor. The reduction of production in the treatment compared to the control was obtained by the formula:

$$
\text { Rprod\% }=\left(1-\frac{\mathrm{Pt}}{\mathrm{Pc}}\right) \times 100
$$

Rprod $\%=$ Reduction of the production; $\mathrm{Pt}=$ Production of treatment; and $\mathrm{Pc}=$ Production of the control.

To obtain the effect of the insecticide (E\%), the modified formula of Peters and Poullot (2004) was used:

$$
\mathrm{E} \%=100-(100-\mathrm{Cm} \%-\operatorname{Rinf} \%-\text { Rprod } \%)
$$

The formulas used follow the IOBC standards (International Organization for Biological and Integrated Control of Noxious Animals and Plants). A value of zero (0) was assigned to the calculation of E\% when the factors $\mathrm{Cm} \%$, Rinf\% and $\mathrm{Rprod} \%$ are negative.

The values of the insecticide effect will be classified as: innocuous $(\mathrm{E} \%<30)$, slightly harmful (E\% between 30 and 79), moderately harmful (E\% between 80 and 99) and harmful $(\mathrm{E} \%>99)$.

\section{RESULTS AND DISCUSSION}

Regarding viability, most products kept the IJs alive, since they did not differ from control, maintaining 97 to $99 \%$ of viable IJs. However, Nutriterge ${ }^{\circledR}$ Formula 3 caused a reduction of about $17 \%$ of the viability in relation to the control, and Nem out ${ }^{\circledR}$ was the product that caused the greatest reduction of live IJs, which was $93 \%$ in comparison with the control (Table 2 ).

To verify the infectivity of the IJs, the parameter used was the mortality caused by the IJs in T. molitor larvae. It was observed that the Nutriterge ${ }^{\circledR}$ Formula 3 and Nem out ${ }^{\circledR}$ products caused a reduction of infectivity when compared to the control, and Nem out $^{\circledR}$ caused the greatest difference, reducing the infective capacity of juveniles by $60 \%$. The other products did not differ from the control, maintaining at least $82 \%$ of the juveniles with the capacity to infect the insects (Table 2).

The products that did not affect the viability of the nematodes also did not affect their infectivity. In addition, even observing the drastic viability reduction caused by Nem out ${ }^{\circledR}$, some IJs that remained alive were still able to cause insect mortality, even if considered low in relation to the other treatments. These results can also be observed through the values obtained through the indexes $\mathrm{Cm} \%$ and Rinf $\%$, which confirm the high mortality of IJs when in contact with Nem out ${ }^{\circledR}$ and the reduction of infectivity (Table 2).

In relation to the values obtained for the production (Rprod\%) the products Nutriterge ${ }^{\mathbb{B}}$ Formula 3 and Nem out ${ }^{\circledR}$ caused the highest reduction rates in production, 12.9 and $13.4 \%$, respectively; however, these values were similar to those obtained for other products, for example for Compost $\mathrm{Aid}^{\mathbb{B}}$, $10.7 \%$, and Copper Crop ${ }^{\circledR}, 11.2 \%$ (Table 2). Thus, although Nutriterge ${ }^{\circledR}$ Formula 3 and Nem out ${ }^{\circledR}$ reduced the viability and infectivity of IJs, those that remained alive still had the ability to reproduce, which was similar to the IJs of the other treatments.

The values obtained for the insecticide effect (E\%) for $H$. amazonensis $\mathrm{MC} 01$ demonstrate that Nem out ${ }^{\circledR}$ and Nutriterge ${ }^{\circledR}$ Formula 3 caused adverse effects on IJs. Thus, it can be inferred that in relation to the test of compatibility between soil conditioners and fertilizers with $H$. amazonensis $\mathrm{MC01}$, the product Nem out ${ }^{\circledR}$ was considered harmful to the tested isolate, Nutriterge ${ }^{\circledR}$ Formula 3 was considered slightly harmful and the other products were considered innocuous (Table 2). So, according to the results, the negative association was observed mainly for the interaction between the nematode and the product Nem out ${ }^{\mathbb{B}}$.

Agricultural inputs used to improve soil fertility can have a nematicidal effect, so these products can impact the effectiveness of entomopathogenic nematodes in controlling pests (GEORGIS; GAUGLER, 1991). Products such as soil conditioners and leaf fertilizers have been produced to improve plant development, making them less susceptible to pest and disease attack. Among these products, in their composition many have microorganisms considered beneficial to the plant, providing conditions that favor the plant. 
Table 2. Compatibility of Heterorhabditis amazonensis MC01 with fertilizers and plant extracts.

\begin{tabular}{|c|c|c|c|c|c|c|c|}
\hline Treatment & Viability (\%) & Infectivity (\%) & $\mathrm{Cm} \%{ }^{*}$ & Rinf\%" & Rprod\% $\%$ & $\mathrm{E} \%{ }^{*}$ & IOBC Class \\
\hline Control & $99.6 \pm 0.55 \mathrm{a}$ & $90.0 \pm 7.07 \mathrm{a}$ & 0.0 & 0.0 & 0.0 & 0.0 & Innocuous \\
\hline Compost Aid $^{\circledR}$ & $99.2 \pm 0.84 \mathrm{a}$ & $84.0 \pm 5.47 \mathrm{a}$ & 0.4 & 6.7 & 10.7 & 17.8 & Innocuous \\
\hline Soil Set ${ }^{\circledR}$ & $98.6 \pm 0.55 \mathrm{a}$ & $84.0 \pm 5.47 \mathrm{a}$ & 1.0 & 6.7 & 8.5 & 16.2 & Innocuous \\
\hline Copper Crop $^{\circledR}$ & $98.0 \pm 1.00 \mathrm{a}$ & $82.0 \pm 4.47 \mathrm{ab}$ & 1.6 & 8.9 & 11.2 & 21.7 & Innocuous \\
\hline Condisolo Premium $^{\circledR}$ & $97.8 \pm 1.65 \mathrm{a}$ & $84.0 \pm 5.47 \mathrm{a}$ & 1.8 & 6.7 & 5.8 & 14.3 & Innocuous \\
\hline Nutriterge ${ }^{\circledR}$ Formula 1 & $97.4 \pm 1.14 \mathrm{a}$ & $84.0 \pm 5.47 \mathrm{a}$ & 2.2 & 6.7 & 1.9 & 10.8 & Innocuous \\
\hline Full Matrix ${ }^{\circledR}$ & $97.2 \pm 0.84 \mathrm{a}$ & $82.0 \pm 4.47 \mathrm{ab}$ & 2.4 & 8.9 & 7.8 & 19.1 & Innocuous \\
\hline Nutriterge ${ }^{\circledR}$ Formula 2 & $97.0 \pm 2.00 \mathrm{a}$ & $88.0 \pm 8.36 \mathrm{a}$ & 2.6 & 2.2 & 0.0 & 4.8 & Innocuous \\
\hline Nutriterge ${ }^{\circledR}$ Formula 3 & $82.2 \pm 2.95 \mathrm{~b}$ & $70.0 \pm 7.07 \mathrm{~b}$ & 17.4 & 22.2 & 12.9 & 52.6 & Slightly harmful \\
\hline Nem out ${ }^{\circledR}$ & $6.4 \pm 3.05 c$ & $30.0 \pm 7.07 \mathrm{c}$ & 93.6 & 66.7 & 13.4 & 173.6 & Harmful \\
\hline CV (\%) & 1.94 & 7.92 & & & & & \\
\hline
\end{tabular}

Means followed by the same letter in the column do not differ according to Tukey test at $5 \%$ probability.

${ }^{*} \mathrm{Cm} \%=$ corrected mortality; Rinf $\%$ = reduction of infectivity; $\operatorname{Rprod} \%=$ reduction of the production; $\mathrm{E} \%=$ effect of the insecticide. 
Considering the products tested regarding compatibility with $H$. amazonensis, two of them contain bacteria in their composition. One of them, Compost $\mathrm{Aid}^{\circledR}$, did not cause mortality of the IJs, being considered innocuous; however, Nem out ${ }^{\mathrm{B}}$ was considered harmful to the tested nematode (Table 1). This difference may have occurred as a function of the species of bacteria present in the product composition, as well as the enzymes produced by them. In the product Nem out ${ }^{\mathbb{B}}$, the bacteria that are part of the product composition are not specified, but only the microbial count, indicating the presence of microorganisms. This difference between these products could be observed due to the difference between the species of microorganisms that constitute the products, as well as the other components of the formulas, which can also influence the action on the nematode.

Bacteria are capable of producing enzymes such as proteases and lipases that act on the pathogenicity and virulence of nematodes. Some species of Bacillus nematocida Huang, Niu, Zhou and Zhang degrade the juvenile cuticle of Panagrellus redivivus L. (Nematoda: Rhabditida: Panagrolaimidae), causing 95\% mortality after $48 \mathrm{~h}$ exposure to the enzyme extract of this bacterium (NIU et al., 2006). Huang et al. (2009) found that Stenotrophomonas maltophilia Palleroni and Bradbury presents nematicidal activity against Bursaphelenchus xylophilus (Steiner and Buhrer) (Nematoda: Tylenchida: Parasitaphelenchidae) and $P$. redivivus, and the proteases produced by this bacterium act causing cuticular degradation.

Infective juveniles maintain the cuticle of the second juvenile stage, so they have a double cuticle; the nematodes that retain the cuticle of the second juvenile stage are less affected by the presence of biotic and abiotic factors (SPIRIDONOV, 2017). According to Hussaini (2017) it is difficult for the parasite fungus of nematodes Hirsutella rhossiliensis Minter and Brady to adhere to the cuticle because of the double cuticle of the IJs, reducing parasitism. Thus, this is a condition that often makes EPNs have high compatibility with phytosanitary products used in the field, favoring their use in programs of integrated pest management. However, each case should be studied in particular, as there are results that prove the adverse effect of products used in agricultural areas in IJs.

Sabino et al. (2014) tested the action of phytosanitary products in contact with $H$. amazonensis RSC5 and H. amazonensis JPM4 and verified that although they do not cause mortality of IJs, some products caused reduction of infectivity to
Galleria mellonella L. (Lepidoptera: Pyralidae) larvae, and the authors associate this characteristic with a decrease in the lipid reserves of the nematodes. According to Menti et al. (2003), the nematode's lipid reserve can be affected by changes that occur in the environment, directly affecting the survival and infectivity of these organisms.

Different products formulated with plant extracts have been used in order to control pests and diseases (ISMAN, 2006). The action that these products exert on non-target organisms should be investigated in order to verify the selectivity to natural enemies and pollinators. As Nutriterge ${ }^{\circledR}$ Formula 3 was considered slightly harmful (Table 2) and is the product with the highest amount of pyroligneous extract (Table 1), can be inferred that possibly this is the component of the formula that is contributing to the deleterious effect to the nematode, since the only other component (active ingredient) of this product is neem extract, which is present in the other formulations of this product in larger amounts, Nutriterge ${ }^{\circledR}$ Formula 1 and Nutriterge ${ }^{\circledR}$ Formula 2 (Table 1), thus excluding this component as the agent causing the negative action in the nematode.

Rohde et al. (2002) tested the association of EPNs with extracts of leaves, branches and fruits of the plants Melia azedarach L. (Meliaceae), Ruta graveolens L. (Rutaceae), Zingiber officinale Roscoe (Zingiberaceae) and bulbs of Allium sativum L. (Alliaceae ), with the objective of using them in the control of Ceratitis capitata (Wiedemann) (Diptera: Tephritidae). The authors verified that the extracts were incompatible with Steinernema carpocapsae (Weiser) All and with $H$. amazonensis JPM4 at a concentration of $40 \% \mathrm{w} / \mathrm{v}$, demonstrating that even products considered natural can negatively influence the nematode's survival.

Ethanolic plant extracts can inhibit the development and the cuticle exchange of EPNs at all stages of their development (GLAZER et al., 2015). Santhi et al. (2017) tested in Heterorhabditis bacteriophora extracts from the plants Salix alba L. (Saliaceae), Inula viscosa L. (Asteraceae) and Quercus calliprinos Webb (Fagaceae) and found that these treatments caused a reduction in the development of the vulva and the number of eggs produced by this nematode species.

The tested products Copper Crop ${ }^{\circledR}$, Soil Set $^{\circledR}$, Full Matrix ${ }^{\circledR}$, Condisolo Premium ${ }^{\circledR}$ present in their composition mineral nutrients that have the potential to influence the action of the EPNs when applied to the soil, since Bednarek and Gaugler (1997) demonstrated that Steinernema feltiae (Filipjev) and $H$. bacteriophora are influenced by 
the addition of NPK in the soil. The authors verified that potassium nitrate and potassium phosphate increased the infectivity of IJs to G. mellonella larvae when kept in contact for 1 day, but exposure over 10 days in high concentrations caused a reduction of the infectivity and of the number of juveniles produced. However, the contact with calcium nitrate did not affect the IJs, even after 40 days of exposure. The authors emphasize that the negative influence of the use of inorganic fertilizers is probably associated with the high concentrations tested and a high period of exposure and at the doses usually applied in the field, but no negative effect was observed on the nematodes, allowing the associated application.

Nematodes of the genus Heterorhabditis tend to be more sensitive to environmental changes than steinernematids (GREWAL et al., 1998), while products tested under $H$. amazonensis $\mathrm{MC} 01$ that have different nutrient sources present in inorganic fertilizers were considered innocuous to infective juveniles.

\section{CONCLUSIONS}

H. amazonensis MC01 was compatible with most of the tested products, which highlights the potential of simultaneous application.

Nutriterge $^{\circledR} \quad$ Formula 3 was considered slightly harmful and Nem out ${ }^{\mathbb{B}}$ considered harmful.

Field tests should be performed with these products in order to prove the deleterious effect on the nematode tested. These results could allow a reduction of expenses and make the establishment of integrated pest management programs viable.

RESUMO: Nematoides entomopatogênicos são inimigos naturais de insetos-praga presentes no solo; no entanto, o uso de insumos agrícolas pode afetar a ação desses organismos. O objetivo deste estudo foi avaliar os efeitos da exposição de Heterorhabditis amazonensis MC01 com fertilizantes de solo contendo diferentes ingredientes ativos, a fim de verificar a influência na viabilidade, infectividade e produção do nematoide em larvas de Tenebrio molitor L. Foram testados nove produtos, incluindo fertilizantes e condicionadores de solo, utilizando o protocolo adaptado da IOBC/WPRS. Os juvenis infectantes foram expostos à maior concentração recomendada de cada produto por período de $48 \mathrm{~h}$. Após, esse período os valores de viabilidade, infectividade, redução da produção e efeito inseticida foram obtidos e os produtos foram classificados de acordo com os critérios da IOBC. Dessa forma, o nematoide $H$. amazonensis MC01 foi compatível com a maioria dos produtos nas condições testadas, podendo estar presente no solo ao mesmo tempo. No entanto, o produto Nutriterge ${ }^{\circledR}$ Fórmula 3 foi considerado ligeiramente prejudicial e Nem out ${ }^{\circledR}$ foi considerado prejudicial. Outros testes de campo devem ser realizados com esses produtos para comprovar o efeito deletério sobre o nematoide testado.

PALAVRAS-CHAVE: Controle biológico. Extrato botânico. Heterorhabditidae. Agricultura orgânica.

\section{REFERENCES}

ANDALÓ, V.; MOREIRA, G. F.; MOINO JUNIOR, A. Studies of two new populations of Heterorhabditis amazonensis (Rhabditida: Heterorhabditidae). Nematropica, v. 39, n. 2, p. 199-211, 2009.

http://journals.fcla.edu/nematropica/article/view/64480/0.

BEDNAREK, A.; GAUGLER, R. Compatibility of soil amendments with entomopathogenic nematodes. Journal of Nematology, v. 29, n. 2, p. 220-227, 1997.

https://www.ncbi.nlm.nih.gov/pmc/articles/PMC2619768/.

CHEN, S. Y.; DICKSON, D. W. A technique for determining live second-stage juveniles of Heterodera glycines. Journal of Nematology, v. 32, n. 1, p. 117-121, 2000.

https://www.ncbi.nlm.nih.gov/pmc/articles/PMC2620428/.

DOLINSKI, C.; MONTEIRO, C.; ANDALÓ, V.; LEITE, L. G. Studies on entomopathogenic nematodes in Brazil: past and future. Nematoda, v. 4, p. 1-14, 2017. http://dx.doi.org/10.4322/nematoda.01017. 
GEORGIS, R.; GAUGLER, R. Predictability in biological control using entomopathogenic nematodes. Journal of Economic Entomology, v. 84, n. 3, p. 713-720, 1991. https://doi.org/10.1093/jee/84.3.713.

GLAZER, I.; SALAME, L.; DVASH, L.; MUKLADA, H.; AZAIZEH, H.; MRENY, R.; MARKOVICS, A.; LANDAU, S. Y. Effects of tannin-rich host plants on the infection and establishment of the entomopathogenic nematode Heterorhabditis bacteriophora. Journal of Invertebrate Pathology, v. 128, p. 31-36, 2015. https://doi.org/10.1016/j.jip.2015.02.002.

GREWAL, P. S.; NARDO, E. A. B.; AGUILLERA, M. M. Entomopathogenic nematodes: potential for exploration and use in South America. Neotropical Entomology, v. 30, n. 2, p. 191-205, 2001.

http://www.scielo.br/pdf/ne/v30n2/a01v30n2.

GREWAL, P. S.; WEBBER, T.; BATTERLEY, D. Compatibility of Steinernema feltiae with chemicals used in mushroom production. Mushroom News, v. 46, p. 6-10, 1998.

HUANG, X. W.; LIU, J. W.; DING, J.; HE, Q. H.; XIONG, R.; ZHANG, K. The investigation of nematocidal activity in Stenotrophomonas maltophilia G2 and characterization of a novel virulence serine protease.

Canadian Journal of Microbiology, v. 55, n. 8, p. 934-942, 2009. https://doi.org/10.1139/W09-045.

HUSSAINI, S. S. Entomopathogenic nematodes: ecology, diversity and geographical distribution. In: ABDELGAWAD, M.; ASKARY, T. H.; COUPLAND, J. (Ed.). Biocontrol agents: entomopathogenic and slug parasitic nematodes. Wallingford: CABI Publishing, 2017, p.88-142.

ISMAN, M. B. Botanical insecticides, deterrents, and repellents in modern agriculture and an increasingly regulated world. Annual Review Entomology, v. 51, p. 45-66, 2006.

https://doi.org/10.1146/annurev.ento.51.110104.151146.

KAYA, H. K.; BURLANDO, T. M.; CHOO, H. Y.; THURSTON, G. S. Integration of entomopathogenic nematodes with Bacillus thuringiensis or pesticidal soap for control of insect pests. Biological Control, v. $5, \mathrm{n}$. 3 p. 432-441, 1995. https://doi.org/10.1006/bcon.1995.1052.

KOPPENHÖFER, A. M.; GREWAL, P. S. Compatibility and interaction with agrochemicals and biocontrol agents. In: GREWAL, P. S.; EHLERS, R. U.; SHAPIRO-ILAN, D. I. (Ed.). Nematodes as biocontrol agents. Cambridge: CABI, 2005, p. 363-381.

MENTI, H.; PATEL, M. N.; WRIGHT, D. J.; PERRY, R. N. Lipid utilization during storage of the entomopathogenic nematodes Steinernema feltiae and Heterorhabditis megidis from Greece and the UK. Nematology, v. 5, n. 1, p. 31-37, 2003. https://doi.org/10.1163/156854102765216669.

NISHIMATSU, T.; JACKSON, J. J. Interaction of insecticides, entomopathogenic nematodes, and larvae of the western corn rootworm (Coleoptera: Chrysomelidae). Journal of Economic Entomology, v. 91, n. 2, p. 410418, 1998. https://doi.org/10.1093/jee/91.2.410.

NIU, Q. H.; HUANG, X. W.; ZHANG, L.; LI, Y. X.; LI, J.; YANG, J. K.; ZHANG, K. Q. A neutral protease from Bacillus nematocida, another potencial virulence factor in the infection against nematodes. Archives of Microbiology, v. 185, n. 6, p. 439-448, 2006. https://doi.org/10.1007/s00203-006-0112-x.

PETERS, A.; POULLOT, D. Side effects of surfactants and pesticides on entomopathogenic nematodes assessed using advanced IOBC guidelines. IOBC / WPRS Bulletin, v. 27, n. 6, p. 67-72, 2004. https://www.researchgate.net/publication/258105173.

POTRICH, T. D.; LORINI, I.; VOSS, M.; STEFFENS, M. C. S.; PAVANI, D. P. Methodology to rear Tenebrio molitor in laboratory to obtain larvae. Passo Fundo: Embrapa Trigo, 2007. http://www.cnpt.embrapa.br/biblio/do/p_do82_12.htm. 
ROHDE, C.; MOINO JÚNIOR, A.; MERTZ, N. R.; KRUPA, P.; RAMALHO, K. R. O. Compatibilidade de nematoides entomopatogênicos e extratos vegetais aquosos visando o controle da mosca-das-frutas Ceratitis capitata (Wiedemann) (Diptera: Tephritidae). Semina. Ciências Agrárias, v. 34, n. 3, p. 1033-1042, 2013. https://doi.org/10.5433/1679-0359.2013v34n3p1033.

SABINO, P. H. S.; MOINO JÚNIOR., A.; ANDALÓ, V. Effects of some insecticides on the neutral lipid percentage, survival and infectivity of Steinernema carpocapsae ALL and Heterorhabditis amazonensis JPM 4. Nematoda, v. 1, p. 1-7, 2014. https://doi.org/10.4322/nematoda.02014.

SABINO, P. H. S.; MOINO JÚNIOR, A.; ANDALÓ, V.; LIMA, L. M. Z.; FILGUEIRAS, C. C. Effects of insecticides on $\mathrm{CO} 2$ release by entomopathogenic nematodes (Nematoda: Rhabditida) and development of their mutualistic bacteria. Revista Colombiana de Entomología, v. 43, n. 1, p. 38-40, 2017. http://www.scielo.org.co/scielo.php?script=sci_arttext\&pid=S0120-04882017000100038.

SANTHI, V. S.; SALAME, L.; DVASH, L.; MUKLADA, H.; AZAIZEH, H.; MRENY, R.; AWWAD, S.; MARKOVICS, A.; LANDAU, S. Y.; GLAZER, I. Ethanolic extracts of Inula viscosa, Salix alba and Quercus calliprinos, negatively affect the development of the entomopathogenic nematode, Heterorhabditis bacteriophora - a model to compare gastro-intestinal nematodes developmental effect. Journal of Invertebrate Pathology, v. 145, p. 39-44, 2017. https://doi.org/10.1016/j.jip.2017.03.005.

SOMMERVILLE, R. I.; DAVEY, K. G. Diapause in parasitic nematodes: a review. Canadian Journal of Zoology, v. 80, n. 11, p. 1817-1840, 2002. https://doi.org/10.1139/z02-163.

SPIRIDONOV, S. E. Entomopathogenic nematodes of the families Steinernematidae and Heterorhabditidae: morphology and taxonomy. In: ABD-ELGAWAD, M.; ASKARY, T. H.; COUPLAND, J. (Ed.). Biocontrol agents: entomopathogenic and slug parasitic nematodes. Wallingford: CABI Publishing, 2017, p. 45-62. https://doi.org/10.1079/9781786390004.0045.

VAINIO, A. Guideline for laboratory testing of the side-effects of pesticides on entomophagous nematodes Steinernema spp. IOBC/WPRS Bulletin, v. 15, p. 145-147, 1992. http://agris.fao.org/agrissearch/search.do?recordID=FR9206275. 